\title{
Corporate Social Responsibility Disclosure and Cost of Equity of ASEAN-5 Public Companies
}

\author{
Randi Anto ${ }^{1}$, Irene Rini Demi Pangestuti ${ }^{2}$, Sugeng Wahyudi ${ }^{2}$ \& Rezy Ayu Ramadhanti ${ }^{2}$ \\ ${ }^{1}$ Doctoral Program in Economics, Universitas Diponegoro, Semarang, Indonesia \\ ${ }^{2}$ Faculty Economics and Business, Universitas Diponegoro, Semarang, Indonesia \\ Correspondence: Irene Rini Demi Pangestuti, Faculty Economics and Business, Universitas Diponegoro, Semarang, \\ Indonesia. Tel: 62-812-289-5183.
}

Received: January 26, 2021

Accepted: March 2, 2021

Online Published: April 14, 2021

doi:10.5430/rwe.v12n2p334

URL: https://doi.org/10.5430/rwe.v12n2p334

\begin{abstract}
This research aims to analyze the influence of corporate social responsibility (CSR) disclosure, leverage, and ownership structure - consisting of institutional ownership, managerial ownership and concentrated ownership - on cost of equity with book-to-market ratio and firm size as control variables. The population was non-financial public companies listed in ASEAN. There was a total of 76 companies obtained using a purposive sampling technique. The data was analyzed using the multiple regression technique. The results show that the data is normally distributed and has met the requirements for using the multiple linear regression models. The findings indicate that the CSR and leverage have a positive and significant influence on cost of equity. Similarly, the institutional ownership also has a positive and significant influence on cost of equity. However, the managerial ownership and concentrated ownership have a negative and significant influence on cost of equity. Meanwhile, the book-to-market ratio has a negative and significant influence on cost of equity. In contrast, the firm size has a positive and significant influence on cost of equity.
\end{abstract}

Keywords: corporate social responsibility disclosure, leverage, ownership structure, cost of equity

\section{Introduction}

\subsection{Background of the Study}

One of the company roles is as an agent for a country's development. It is because companies can offer job opportunities for the community, build various economic facilities and improve the employees' welfare. In developing the business, the companies may experience problems related to funding. These problems come from the fund needed by the companies yet the bank can no longer fulfill. Capital market is one possible solution to get funds for the companies. Therefore, the companies need to spend cost of equity. According to Mulyati (2017), the cost of equity (COE) refers to the cost paid by a company to attract investors to invest their money in stocks and to maintain a relationship with them. In a company, the cost of equity is such an important component of business valuation. An investor expects his investment to grow at the cost of equity. It is also closely related to investment risk.

Many literature claims that the CSR disclosure will have a direct influence on the cost of equity of a company. Companies with a strong CSR commitment have a higher revenue quality as the CSR decreases the information asymmetry which simultaneously decreases the earning management opportunity (Choi, Choi, \& Byun, 2018). The CSR is highly related to the company's commitment to contribute to sustainable development, stakeholder interests, and improving social conditions (Usman, 2020; Velte, 2017). Its practice can be implemented using the triple bottom line theory. In the triple bottom line theory, the companies pay attention not only to profit but also to environmental and social aspects. One of the reasons why the CSR activities are related to risk management is because CSR allows companies to lower the possibility of a social and environmental crisis that will eventually lead to a higher cash outflow (Faisal, Andiningtyas, Achmad, Haryanto, \& Meiranto, 2018; Mai, 2017; Usman, 2020).

Further, companies prefer to use debt to fund their business activities because the costs they bear are less than the issuance of new shares to fund the company's operational activities (Myers, 1984). Meanwhile, leverage is a ratio that measures the company's long-term debt. In this study, it is measured using the formula Total Debt to Total Assets. Khlif, Samaha, and Azzam (2015); Sutomo, Wahyudi, Rini Demi Pangestuti, and Muharam (2019, 2020) found that 
the leverage had a positive effect on the company's cost of equity. This happened as the leverage reflected the company's financial risk, which also reflected the company's capital structure and helped understanding the risk of uncollectible debt.

In addition, companies that are not able to manage their debts properly are at risk of default and will have fatal consequences such as bankruptcy. To optimize the company performance, a system that can monitor the company performance is needed. A well-managed company's ownership structure is a form of corporate governance that can equalize the interests of company owners and managers (Adeabah, Gyeke-Dako, \& Andoh, 2019; Muharam, Mawardi, Handriani, Puryandani, \& Robiyanto, 2020; Puryandani, Kusumawati, \& Robiyanto, 2020; Robiyanto, Anggraeni, Nugraha, \& Lako, 2019; Robiyanto, Putra, \& Lako, 2019; Susanto \& Robiyanto, 2020).

One important aspect of the company's ownership structure is institutional ownership. It refers to institutions that have and manage their investment funds in the capital market objectively in order to make their clients prosperous (Crane, Michenaud, \& Weston, 2016; Handriani \& Robiyanto, 2019; Herman \& Subowo, 2016; Krismiaji, Wiratno, \& Ashari, 2019). In general, there are five types of institutional ownership: 1) Pension Funds, 2) Mutual Funds, 3) Banks, 4) Asset Management, and 5) Insurance Companies.

According to Krismiaji et al. (2019), another important aspect of ownership structure is concentrated ownership. It enables the owners to have higher voting rights, so that they can have a broader supervision which in turn can reduce the opportunistic behavior of company managers. The concentrated ownership can also help in eliminating agency problems between the company owners and managers which will then reduce the cost of equity (Iskandar, Hassan, Sanusi, \& Mohamed, 2017). Meanwhile, managerial ownership is part of the company's ownership structure. It helps the management's personal wealth to be increasingly tied to the company's wealth so that the management will try to reduce the risk of losing its wealth (Chen, 2013; Herman \& Subowo, 2016; Muryanti, 2017). The increase in ownership from the management causes the managers to make decisions that benefit the shareholders as they are also part of the shareholders, thus there will be a decrease in the conflict of interest.

Next, the valuation of a company is crucial for investors because they believe the company they invest in can provide an expected return, or even higher. Further, book-to-market ratio is a ratio used by investors to determine the company value by comparing the company's book value with the stock market value. The published book-to-market ratio is information provided by the company which then becomes a signal for investors to assess the company's performance. In addition to assessing the company by using its book-to-market ratio, the investors can assess the company through other factors that affect the company's financial performance, such as firm size. Firm size is an indicator that measures the size of the company as indicated by the total assets owned by the company as larger companies can attract more media and analyst coverage, which reduces to lower the risk of information asymmetry leading to lower COE (Dang, Li, \& Yang, 2018; Handriani \& Robiyanto, 2019; Huynh, Jacho-Chávez, Petrunia, \& Voia, 2015).

Based on the aforementioned description, the study regarding the effect of some variables such as corporate social responsibility (CSR) disclosure, leverage, and ownership structure - consisting of institutional ownership, managerial ownership and concentrated ownership - on cost of equity is important, also the usage of several control variables such as book-to-market ratio and firm size. The purpose of this study is to analyze the influence of corporate social responsibility (CSR) disclosure, leverage, and ownership structure - consisting of institutional ownership, managerial ownership and concentrated ownership - on cost of equity with book-to-market ratio and firm size as control variables.

\subsection{Statement of Hypotheses}

The CSR disclosure published by the company will reduce the information asymmetry within the company which causes the agency cost to increase. In addition, the CSR disclosure is also a signal that the company gives to the investors. Dhaliwal, Li, Tsang, and Yang (2011) examined the relationship between CSR disclosure and cost of equity, and found a negative relationship between them. A research conducted by Wang, Huang, Gao, Ansett, and Xu (2015) indicated that investing in CSR activities provided a significant contribution in reducing the company's cost of equity. Based on the theoretical explanation and results of previous researches, the first hypothesis that can be formulated is as follows:

H1: CSR disclosure has a negative influence on cost of equity

The agency theory explains that the higher the leverage, the higher the level of wealth transfer from the creditors to company's shareholders. Therefore, the companies with a high leverage have a higher obligation to meet the needs of information of long-term creditors (Akhmadi, Nurohman, \& Robiyanto, 2020; Nugroho \& Sung Suk, 2019). The 
companies with a lower leverage will fund their assets using their own capital. A research conducted by Dhaliwal et al. (2011) found a positive influence on the cost of equity. Therefore, based on the description above, the second hypothesis that can be proposed is:

H2: Leverage has a positive influence on cost of equity

The agency theory explains that conflicts often occurred due the information asymmetry between the two parties. The supervision of institutional investors will improve the management performance and prevent fraud that will be committed by managers so that the company's performance will also be better. Jensen and Meckling (1976) stated that institutional ownership is one of the tools used to reduce the agency problems that occur between the managers and shareholders. Handriani and Robiyanto (2019); Pham and Zein (2012) found a negative relationship between the institutional ownership and cost of equity. Therefore, the third hypothesis that can be proposed is as follows:

H3: Institutional ownership has a negative influence on cost of equity

The agency theory describes that every company can experience agency problems caused by the information asymmetry between the management and shareholders (Jensen \& Meckling, 1976). Managerial ownership will reduce the company's cost of equity as a high managerial ownership help the managers to be much more concerned about the shareholders' interests for they are also part of them. Thus, the managers will be willingly to improve their performance and reduce the company risk (Herman \& Subowo, 2016; Muryanti, 2017). A study by Chen (2013) found a negative relationship between the managerial ownership and cost of equity. Therefore, according to the explanation above, the fourth hypothesis that can be proposed is:

H4: Managerial ownership has a negative influence on cost of equity

In the agency theory, it is explained that a company can experience an agency problem occurred between the management and company's shareholders (Jensen \& Meckling, 1976). One of the ways to lower the possibility of the agency problems in the company is through company supervision. It can be carried out by concentrated shareholders. Research conducted by Huang, Ritter, and Zhang (2016); Khlif et al. (2015) found a negative relationship between concentrated ownership and cost of equity. Therefore, the fifth hypothesis that can be proposed is:

H5: Concentrated ownership has a negative influence on cost of equity

Book-to-market ratio is a ratio regularly used by investors in assessing a company. Before deciding to invest in a company, the investors need a lot of information (Fama \& French, 1992). This ratio helps the investors to get information about the state of the company. The signaling theory describes various forms of information conveyed by the company management to the company stakeholders. This information can be used as a signal for all stakeholders, including the investors. Research by Arce and Mora (2002); Plumlee, Brown, Hayes, and Marshall (2015) confirmed a negative relationship between the book-to-market ratio and cost of equity. Thus, the sixth hypothesis that can be proposed is:

H6: Book-to-market ratio has a negative influence on cost of equity

In the agency theory, Jensen and Meckling (1976) stated that the bigger the firm size, the greater the disclosure should be. This theory explains that the companies with a larger size have a greater agency cost. To reduce the agency cost, the companies must disclose more information. In addition, the signaling theory states that all information published by the company can be a signal for all stakeholders, including the investors. Research by Dhaliwal et al. (2011); Pham and Zein (2012) showed that there was a negative relationship between firm size and cost of equity. Thus, the seventh hypothesis that can be proposed is:

H7: Firm size has a negative influence on cost of equity

\section{Method}

The dependent variable in this study is cost of equity, while the independent variables are CSR disclosure, leverage, institutional ownership, managerial ownership, and concentrated ownership. Meanwhile, the control variables are book-to-market ratio and firm size. In this study, the cost of equity is calculated using the Capital Asset Pricing Model (CAPM) as follow: COE: Risk free Rate + (Beta x Country Risk Premium). In this study, the CSR disclosure is used as an independent variable which refers to the score of a company's CSR activities measured on the basis of the company's environmental, social, and governance (ESG) information disclosed as follow: CSR Disclosure = Total ESG Score. Leverage is a company's long-term debt used to fund the company's operation. Institutional ownership refers to the total percentage of company's share ownership owned by an institution. Managerial ownership is the total percentage of company's share ownership owned by the company management. Concentrated ownership is the percentage of company's share ownership calculated from the three largest shareholders. In this 
study, book-to-market ratio is a control variable and it refers to the ratio for a company prospect. Firm size is a control variable and it refers to the size of a company as seen through the assets owned. In this study, the firm size is calculated as follows: Firm Size $=$ Log Total Assets.

The population was ASEAN-5 going public non-financial companies in 2014-2018. There were a total of 76 companies involved, with the period of observation during 2014-2018. The sample was taken using a purposive sampling method. The criteria are as follow: (1) An ASEAN-5 non-financial public company in 2014-2018; (2) An ASEAN-5 non-financial public company that publishes its annual report of 2014-2018; (3) Have a complete data consisting of cost of equity, CSR disclosure, leverage, institutional ownership, managerial ownership, concentrated ownership, book-to-market ratio, and firm size. 76 samples and 380 observations obtained in this study.

The data used was a secondary data in the form of audited annual reports and published by the company. The data consisted of data on cost of equity, CSR disclosure, leverage, institutional ownership, concentrated ownership, book-to-market ratio which could be obtained by accessing Bloomberg. Meanwhile, data on firm size was taken from the annual financial reports in the period of 2014-2018.

The data was analyzed using multiple regression technique. The following is the regression model used in this study.

$$
\mathrm{COE}=\beta_{0}+\beta_{1} C S R D+\beta_{2} L E V+\beta_{3} I N S T O W N+\beta_{4} \text { CONTOWN }+\beta_{5} B M+\beta_{6} S I Z E+\varepsilon
$$

Notes:

CSRD: CSR Disclosure

LEV: Leverage

INSTOWN: Institutional Ownership

MANAOWN: Managerial Ownership

CONTOWN: Concentrated Ownership

BM: Book-to-Market ratio

SIZE: Firm Size

$\varepsilon$ : Error

\section{Results}

\subsection{Descriptive Statistics}

A descriptive analysis is used to determine the description of a data instead of testing the hypotheses of a study. It also provides calculations to provide clarity on the state of the data to be processed.

Table 1. Descriptive statistics of research variables

\begin{tabular}{llllll}
\hline & $\mathrm{N}$ & Minimum & Maximum & Mean & Std. deviation \\
\hline COE & 380 & 3.14 & 18.26 & 9.1125 & 2.20425 \\
\hline CSRD & 380 & 10.09 & 69.00 & 29.9068 & 13.88553 \\
\hline LEV & 380 & 10.00 & 39.78 & 22.9407 & 7.12985 \\
\hline INSTOWN & 380 & 30.42 & 69.89 & 53.5296 & 9.22606 \\
\hline MANOWN & 380 & 1.00 & 47.54 & 8.9751 & 10.80635 \\
\hline CONTOWN & 380 & 30.78 & 72.03 & 51.9765 & 9.30916 \\
\hline BM & 380 & 1.18 & 109.22 & 12.5136 & 6.02053 \\
\hline SIZE & 380 & 7.87 & 10.66 & 9.4714 & .54691 \\
\hline Valid N (listwise) & 380 & & & & \\
\hline
\end{tabular}

Source: Processed secondary data, 2020

Table 1 show that the total data used in this study is 380 observational data. In the CSR disclosure variable, it can be seen that the minimum value 10.09 , the maximum value is 69.00 , while the average value is 29.9068 . The standard deviation value of 13.88553 indicates that the data distribution was not homogeneous as it is not close to zero.

In addition, Table 1 also shows the leverage variable has a minimum value of 10.00 , a maximum value of 39.78 and 
an average value of 22.9407 with a standard deviation value of 7.12985. Further, the institutional ownership variable has a minimum value of 30.42 and a maximum value of 69.8 . They indicate that most of the shares of ASEAN-5 non-financial public companies were owned by institutions. The average value of institutional ownership variable is 53.5296 which also confirm that the institutional ownership was considered high. Meanwhile, the standard deviation value is 9.22606 which show that the data was not homogeneous as the standard deviation value is not close to zero.

Next, the managerial ownership has a minimum value of 1.00 in several companies. Meanwhile, the maximum value is 47.54. This result shows that the managerial ownership in ASEAN-5 non-financial public companies was low and most of the shares were owned by institutions. Its average value is 8.9571 which were considered low. The standard deviation value is 10.80635 , indicating that the data was not homogeneous because the standard deviation value is not close to zero.

Furthermore, the concentrated ownership variable has a minimum value of 30.78 and a maximum value of 72.03 . These results indicate that many companies had concentrated ownership. Meanwhile, the average value is 51.9765 which showed that the concentrated ownership was high. The standard deviation value is 9.30916 which explain that the data distribution was not homogeneous because the standard deviation value is not close to zero.

The book-to-market ratio variable has a minimum value of 1.18 and a maximum value of 109.22. This shows that the value of ASEAN-5 non-financial public companies were not good enough in the eyes of investors as the book-to-market ratio value is greater than 1 . Meanwhile, the average value is only 12.5136 , indicating that the overall value was high enough for investors. While the standard deviation value is 6.02053 and describes that the data distribution in this study was not homogeneous because the standard deviation value is not close to zero.

Last, the firm size variable has a minimum value of 7.87 and a maximum value of 10.66 . These results show that the companies were trying to increase their firm size every year. The average value is 9.4714 and shows that overall, the sample illustrates that the firm size of the company was quite small. Meanwhile, the standard deviation value is .54691 and means that the research data was homogeneous because the standard deviation value is close to zero.

\subsection{Statistics and Data Analysis}

Based on the research results, the F-test value is 6.700 with a significance value of 0.000 , and the F-table value of 2.03. This means that this study has a significant result because F-count > F-table. From this test, it can be seen that all independent variables influence the dependent variable. In addition, the $\mathrm{R}^{2}$ value of the study is 0.296 or $29.6 \%$. This means that the level of the model's ability to explain the dependent variable is $29.6 \%$. Meanwhile, the rest $70.4 \%$ can be explained by other variables not included in the study.

Table 2. Result of statistic test

\begin{tabular}{llllll}
\hline Model & \multicolumn{2}{l}{ Unstandardized coefficients } & Standardized coefficients & \multirow{2}{*}{ Sig. } \\
\cline { 2 - 5 } & $\mathrm{B}$ & Std. error & Beta & & \\
\hline (Constant) & 10.237 & .699 & & 16.224 & .000 \\
\hline CSRD & .037 & .010 & .251 & 3.885 & .020 \\
\hline LEV & .048 & .016 & .156 & 3.057 & .010 \\
\hline INSTOWN & .032 & .010 & .163 & 3.270 & .000 \\
\hline CONTOWN & -1.897 & .608 & -.207 & -3.119 & .002 \\
\hline MANOWN & -.062 & .010 & -.308 & -6.216 & .000 \\
\hline BM & -.146 & .045 & -.210 & 3.220 & .010 \\
\hline SIZE & .023 & .255 & .006 & 3.089 & .000 \\
\hline
\end{tabular}

Source: Processed secondary data, 2020

\section{Discussion}

\subsection{The Influence of CSR Disclosure on Cost of Equity}

The result of regression analysis shows that the sig. value is 0.020 which is less than 0.05 . The unstandardized coefficient value is positive. This shows that the first hypothesis is empirically not supported. This study shows that the CSR disclosure has a positive and significant influence on the cost of equity. However, this result is not in line with the signal theory which explains that the information released by the company is such a signal for investors, 
thus the information asymmetry can be reduced and simultaneously reduce the cost of equity. In this study, the CSR disclosure was a signal shared by the company to all stakeholders involved. This insignificant result indicates that the more the CSR information disclosed, the higher the company's cost of equity. On the other hand, this result is supported by Feng, Wang, and Huang (2015) and Utz (2017) which found that the CSR disclosure had a positive effect on the cost of equity. This finding was caused by the low score of CSR disclosure and the lack of experience from the companies in implementing the ESG-based CSR, making the investors thought that the CSR activities carried out did not bring a broad impact.

\subsection{The Influence of Leverage on Cost of Equity}

The result of regression analysis shows that the sig. value is 0.002 which is less than 0.05 . The unstandardized coefficient value is positive. Therefore, the second hypothesis is empirically supported. This study shows that the leverage has a significant positive influence on the cost of equity. It was because the higher the company's leverage, the higher the risk borne by the company. This neither made investors hesitate to invest in the companies as they concerned that the company could not manage the funds nor paid of the debts. This finding is in line with the agency theory which explains that the higher the leverage, the better the transfer of wealth from creditors to company shareholders. Further, this study also supports the signal theory which states that the information released by the company is a signal for all stakeholders involved, especially the investors. This finding is also supported by previous researches such as Dhaliwal et al. (2011) and Nugroho and Sung Suk (2019) which also found that the leverage had a positive effect on the cost of equity.

\subsection{The Influence of Institutional Ownership on Cost of Equity}

The result of regression analysis shows that the sig. value is 0.001 which is less than 0.05 . The unstandardized coefficient value is positive. Therefore, the third hypothesis is empirically not supported. This study finds that the institutional ownership has a positive and significant influence on the cost of equity. The greater the percentage of institutional ownership, the greater the voting power and control rights of the institution over the company. The control right played a big role in the GMS. If there was a difference in opinions in the GMS, the other shareholders' opinion might not be heard and the investors might rethink about investing their shares in the company. Therefore, the companies must provide a high return to attract the investors to increase the cost of equity. However, this finding is not in line with the agency theory by Jensen and Meckling (1976) which explains that the existence of institutional ownership in a company lower the cost of quality born by the company as the problems cause by the information asymmetry between the management and investors decreased. This finding is not consistent with Handriani and Robiyanto (2019); Pham and Zein (2012) found a negative relationship between the institutional ownership and cost of equity.

\subsection{The Influence of Managerial Ownership on Cost of Equity}

The result of regression analysis shows that the sig. value is 0.000 which is smaller than 0.05 . The unstandardized coefficient value is negative. Therefore, the fourth hypothesis is empirically supported. The total percentage of managerial ownership of ASEAN-5 non-financial public companies could lower the cost of equity. It was because the managerial ownership helped the management to feel like they owned the company and be willing to work harder so that they would get benefits from their share ownership. Besides, the managerial ownership also minimized problems caused by the information asymmetry between the management and investors as the managers were also part of the investors. This finding is in line with the agency theory by Jensen and Meckling (1976) which explains that the agency cost will decrease if there is no problem caused by the information asymmetry between the company management and investors. A decrease in the agency cost would also reduce the company's cost of equity. The more the people in management becoming investors, the lower the information asymmetry. This would simultaneously result in a negative effect on the cost of equity. This study is supported by Suhardjanto, Purwanto, Sari, and Setiany (2018) which found that the managerial ownership had a negative influence on the cost of equity.

\subsection{The Influence of Concentrated Ownership on Cost of Equity}

The result of regression analysis shows that the sig. value is 0.002 which is less than 0.05 . The unstandardized coefficient value is negative. Therefore, the fifth hypothesis is empirically accepted. The fifth hypothesis is empirically supported as the largest shareholders had a greater voting power compared to other shareholders and would reduce the opportunistic behavior of the company management. The result of this study is in line with the agency theory which explains that the cost of equity can be reduced due to the reduction in the agency cost borne by the company due to the information asymmetry. The concentrated ownership would reduce the cost of equity by eliminating the conflict of interest between the owners and managers as the largest shareholders' voting right could 
control the management policy. Besides, the company did not have to spend any fees to pay other parties to supervise the company performance. The result is supported by Huang et al. (2016); Khlif et al. (2015).

\subsection{The Influence of Book-to-Market Ratio on Cost of Equity}

The result of regression analysis shows that the sig. value is 0.010 which is less than 0.05 . The unstandardized coefficient value is negative. Therefore, the sixth hypothesis is empirically supported. The sixth hypothesis is empirically supported as the ASEAN-5 non-financial public companies had published their book-to-market ratio value in various media such as Bloomberg and Annual Report which functioned as signals from the companies. The signals helped the investor to assess the company performance and reduced the information asymmetry and its cost of equity. The finding is in line with the agency theory by Jensen and Meckling (1976) which explains that the cost of equity of a company can be reduced if there is no information asymmetry between the company management and investors which eventually reduced the agency cost. Another theory which supports this finding is the signal theory which describes that the information provided by a company is a signal for investors in assessing the company. A previous research by Arce and Mora (2002); Plumlee et al. (2015) confirmed that the book-to-market ratio had a negative effect on the cost of equity because the value of the company published would make it easier for the investors to assess the company, thereby reducing the information asymmetry.

\subsection{The Influence of Firm Size on Cost of Equity}

The result of regression analysis shows that the sig. value is 0.000 which is less than 0.05 . the unstandardized coefficient value is positive. Therefore, the seventh hypothesis is empirically not supported. This finding indicates that the larger the firm size, the higher the risk that must be faced by the company. The investors would ask for a high return for companies with a high risk, causing a high cost of equity. However, this finding is not in line with the agency theory by Jensen and Meckling (1976) which states that the larger the firm size, the greater the disclosure the company have to make to reduce the information asymmetry. This result is in line with a signal theory by Ross (1977) which claims that all information published by a company can be a signal for all stakeholders, including the investors.

\subsection{Conclusions}

The purpose of this study is to analyze the influence of corporate social responsibility (CSR) disclosure, leverage, and ownership structure - consisting of institutional ownership, managerial ownership and concentrated ownership on cost of equity with book-to-market ratio and firm size as control variables. This study found that the CSR disclosure and leverage have a positive effect on cost of equity as well as the institutional ownership. However, the managerial ownership and concentrated ownership have a negative effect on cost of equity. This study also found that the book-to-market ratio has a negative effect on cost of equity. On the contrary, the firm size has a positive effect on cost of equity.

There are some limitations occur in this studies, (1) The number of samples used in this study is limited because there are still few companies implementing ESG-based CSR in the ASEAN-5, especially Indonesia; (2) The limited number of samples is also due to the fact that only a few companies in Indonesia have a managerial stock ownership policy. Some suggestions for future research are (1) Future research are expected to increase the number of variables such as Beta and Revenue Growth as control variables; (2) Future research can add several countries to be included in the study population.

\subsection{Implications}

Based on this study results, some suggestions can be made as follow: (1) Companies are advised to increase the proportion of managerial ownership because stock owned by the management helps the management to feel like they own the company and be willing to improve the company's performance. In addition, the existence of managerial ownership will reduce the information asymmetry and its cost of equity; (3) Companies are advised to increase the proportion of concentrated ownership because the higher the concentrated shareholdings, the less the information asymmetry. It will also cause a decrease in the cost of equity because most of the shareholders are the company's management.

\section{References}

Adeabah, D., Gyeke-Dako, A., \& Andoh, C. (2019). Board gender diversity, corporate governance and bank efficiency in Ghana: a two stage data envelope analysis (DEA) approach. Corporate Governance: The International Journal of Business in Society, 19(2), 299-320. https://doi.org/10.1108/CG-08-2017-0171

Akhmadi, A., Nurohman, N., \& Robiyanto, R. (2020). The mediating role of debt and dividend policy on the effect 
profitability toward stock price. Journal Manajemen dan Kewirausahaan, 22(1), 1-10. https://doi.org/10.9744/jmk.22.1.1-10

Arce, M., \& Mora, A. (2002). Empirical evidence of the effect of European accounting differences on the stock market valuation of earnings and book value. European Accounting Review, 11(3), 573-599. https://doi.org/10.1080/09638180220125616

Chen, M.-Y. (2013). Adjustments in managerial ownership and changes in firm value. International Review of Economics \& Finance, 25, 1-12. https://doi.org/10.1016/j.iref.2012.04.008

Choi, H., Choi, B., \& Byun, J. (2018). The relationship between corporate social responsibility and earnings management: accounting for endogeneity. Investment Management and Financial Innovations, 15(4), 69-84. https://doi.org/10.21511/imfi.15(4).2018.06

Crane, A. D., Michenaud, S., \& Weston, J. P. (2016). The effect of institutional ownership on payout policy: Evidence from index thresholds. Review of Financial Studies, 29(6), 1377-1408.

Dang, C., Li, Z. F., \& Yang, C. (2018). Measuring firm size in empirical corporate finance. Journal of Banking \& Finance, 18, 159-176. https://doi.org/10.1016/j.jbankfin.2017.09.006

Dhaliwal, D. S., Li, O. Z., Tsang, A., \& Yang, Y. G. (2011). Voluntary nonfinancial disclosure and the cost of equity capital: the initiation of corporate social responsibility reporting. Accounting Review, 86(1), 59-100.

Faisal, F., Andiningtyas, E. D., Achmad, T., Haryanto, H., \& Meiranto, W. (2018). The content and determinants of greenhouse gas emission disclosure: Evidence from Indonesian companies. Corporate Social Responsibility and Environmental Management, 25(6), 1397-1406. https://doi.org/10.1002/csr.1660

Fama, E. F., \& French, K. R. (1992). The cross-section of expected return. Journal of Finance, 47(2), 427-465. https://doi.org/10.2307/2329112

Feng, Z.-Y., Wang, M.-L., \& Huang, H.-W. (2015). Equity financing and social responsibility: further international evidence. The International Journal of Accounting, 50(3), 247-280. https://doi.org/10.1016/j.intacc.2015.07.005

Handriani, E., \& Robiyanto, R. (2019). Institutional ownership, independent board, board size, and firm performance: evidence from Indonesia. Contaduría y Administración, 64(3), 1-16. https://doi.org/10.22201/fca.24488410e.2018.1849

Herman, N., \& Subowo, S. (2016). The analysis of the effect of managerial ownership, institutional ownership, leverage, and intellectual capital on corporate performance. Accounting Analysis Journal, 5(3), 147-154. https://doi.org/10.15294/aaj.v5i3.19422

Huang, R., Ritter, J. R., \& Zhang, D. (2016). Private equity firms' reputational concerns and the costs of debt financing. Journal of Financial and Quantitative Analysis, 51(1), $29-54$.

Huynh, K. P., Jacho-Chávez, D. T., Petrunia, R. J., \& Voia, M. C. (2015). A nonparametric analysis of firm size, leverage and labour productivity distribution dynamics. Empirical Economics, 48(1), 337-360. https://doi.org/10.1007/s00181-014-0807-9

Iskandar, T. M., Hassan, N. H., Sanusi, Z. M., \& Mohamed, Z. M. (2017). Board of directors and ownership structure: a study on Small and Medium Enterprises (SMEs) in Malaysia. Journal Pengurusan, 49.

Jensen, M. C., \& Meckling, W. H. (1976). Theory of the firm: Managerial behavior, agency costs and ownership structure. Journal of Financial Economics, 3(4), 305-360. https://doi.org/10.1016/0304-405X(76)90026-X

Khlif, H., Samaha, K., \& Azzam, I. (2015). Disclosure, ownership structure, earnings announcement lag and cost of equity capital in emerging markets. Journal of Applied Accounting Research, 16(1), 28-57. https://doi.org/10.1108/jaar-06-2012-0046

Krismiaji, K., Wiratno, D. H., \& Ashari, S. (2019). Ownership concentration, firm size and information value relevance: Indonesian evidence. Journal of Accounting and Investment, 20(2), 99-113. https://doi.org/10.18196/jai.2002119

Mai, M. U. (2017). Mediation of CSR and profitability on the influences of GCG mechanism to the firm value. Jurnal Keuangan dan Perbankan, 21(2), 253-264.

Muharam, H., Mawardi, W., Handriani, E., Puryandani, S., \& Robiyanto, R. (2020). Corporate governance structure and firm performance in the indonesian capital market. Quality - Access to Success, 21(174), 22-27. 
Mulyati, Y. (2017). The influence of voluntary disclosure, stock beta, and firms size on cost of equity capital. Journal Keuangan dan Perbankan, 21(3).

Muryanti, Y., \& Subowo, S. (2017). The effect of intelectual capital performance, profitability, leverage, managerial ownership, institutional ownership, and independent commissioner on the disclosure of intelectual capital. Accounting Analysis Journal, 6(1), 56-62. https://doi.org/10.15294/aaj.v6i1.11259

Myers, S. C. (1984). Finance theory and financial strategy. Interfaces, 14(1), 126-137.

Nugroho, V. C., \& Sung Suk, K. (2019). The relationship between leverage, maturity, and investment decision: evidence from emerging markets. Organizations and Markets in Emerging Economies, 10(1), 147-164. https://doi.org/10.15388/omee.2019.10.00008

Pham, P. K., \& Zein, J. A. S. J. (2012). Corporate governance and the cost of capital: evidence from Australian companies. Journal of Applied Corporate Finance, 24(3), 84-93.

Plumlee, M., Brown, D., Hayes, R. M., \& Marshall, R. S. (2015). Voluntary environmental disclosure quality and firm value: Further evidence. Journal of Accounting and Public Policy, 34(4), 336-361.

Puryandani, S., Kusumawati, H. A., \& Robiyanto, R. (2020). Corporate governance and earnings management practices in Indonesian banking sector. Quality - Access to Success, 21(176), 102-108.

Robiyanto, R., Anggraeni, A. D., Nugraha, A. K. N. A., \& Lako, A. (2019). The effect of good corporate governance mechanism on firm value of indonesian socially responsible firms. Quality - Access to Success, 20(173), 59-63.

Robiyanto, R., Putra, A. R., \& Lako, A. (2019). The effect of corporate governance and intellectual capital toward financial performance and firm value of socially responsible firms. Contaduría y Administración, 66(1), 1-29. http://doi.org/10.22201/fca.24488410e.2021.2489

Ross, S. A. (1977). The determination of financial structure: The incentive signalling approach. Bell Journal of Economics and Management Science, 8, 23-40.

Suhardjanto, D., Purwanto, P., Sari, K., \& Setiany, E. (2018). Corporate governance and social disclosure: a comparative study of listed hospitality industries in South East Asia. International Journal of Trade and Global Markets, 11(1/2), 21-30. https://doi.org/10.1504/IJTGM.2018.092495

Susanto, A. D., \& Robiyanto, R. (2020). Corporate governance structure and stock price synchronicity. Jurnal Organisasi Dan Manajemen, 16(2), 114-128. https://doi.org/10.33830/jom.v16i2.967.2020

Sutomo, S., Wahyudi, S., Rini Demi Pangestuti, I., \& Muharam, H. (2019). Determinants of financing decision: empirical evidence on manufacturing firms in Indonesia. Investment Management and Financial Innovations, 16(2), 159-170. https://doi.org/10.21511/imfi.16(2).2019.14

Sutomo, S., Wahyudi, S., Rini Demi Pangestuti, I., \& Muharam, H. (2020). The determinants of capital structure in coal mining industry on the Indonesia Stock Exchange. Investment Management and Financial Innovations, 17(1), 165-174. https://doi.org/10.21511/imfi.17(1).2020.15

Usman, B. (2020). CSR performance, firm's attributes, and sustainability reporting. International Journal of Business and Society, 21(2), 521-539.

Utz, S. (2017). Over-investment or risk mitigation? Corporate social responsibility in Asia-Pacific, Europe, Japan, and the United States. Review of Financial Economics. https://doi.org/10.1016/j.rfe.2017.10.001

Velte, P. (2017). Does board composition have an impact on CSR reporting?. Problems and Perspectives in Management, 15(2), 19-35.

Wang, S., Huang, W., Gao, Y., Ansett, S., \& Xu, S. (2015). Can socially responsible leaders drive Chinese firm performance?. Leadership \& Organization Development Journal, 36(4), 435-450. https://doi.org/10.1108/LODJ-01-2014-0006

\section{Copyrights}

Copyright for this article is retained by the author(s), with first publication rights granted to the journal.

This is an open-access article distributed under the terms and conditions of the Creative Commons Attribution license (http://creativecommons.org/licenses/by/4.0/). 